\title{
The Static and Dynamic Review on Consumer Brand Knowledge*
}

\author{
Fang Gao \\ City Development Research Center \\ Shanghai Urban Construction Vocational College \\ Shanghai, China
}

\begin{abstract}
Brand knowledge in consumers' minds is one of the most value-added knowledge for firms. This paper aims to study consumer brand knowledge synthetically from both static and dynamic views, to depict a blueprint of consumer brand knowledge, and to provide theoretical guidance on brand and marketing decisions. Firstly, the content and structure of consumer brand knowledge is studied in view of cognitive psychology. Then the creation and formation process of consumer brand knowledge is explored on the basis of organizational knowledge creation theory.
\end{abstract}

Keywords-consumer; brand knowledge; associative network memory model; organizational knowledge creation theory

\section{INTRODUCTION}

Brand is a kind of knowledge essentially, is one of the most value-added knowledge for firms. In the variety of brand knowledge, the management of consumer brand knowledge is very important. Brand exists in consumers' mind, in how they perceive it. Levitt [1] pointed out: "The difference between marketing and selling is more than semantic. Selling is preoccupied with the seller's need to convert the product into cash, marketing with the idea of satisfying the needs of the customer by means of the product and the whole cluster of things associated with creating, delivering, and finally consuming it." Marketing perspective requires us to understand consumer and understand the brand knowledge lying in the mind of consumer.

Consumer brand knowledge relates to the cognition on brand [2]. Consumer brand knowledge can be defined in terms of the personal meaning about a brand stored in consumer memory, that is, all descriptive and evaluative brand-related information. The importance of knowledge in memory on consumer decision making has been widely proved [3]. Understanding brand knowledge is important, because it influences what will come to the mind of consumer when they think of a brand [4].

The facets and marketing influence of brand knowledge has been studied for years, but the facets are often studied insularly. This paper first statically looks into the content and structure of consumer brand knowledge based on the

*Fund: The project is supported by General Program of Humanities and Social Sciences, Ministry of Education, PRC. cognitive psychology view of knowledge theory; then dynamically studied the creation and formation process of consumer brand knowledge on the basis of organizational knowledge creation theory. We try to integrate brand knowledge and draw a blueprint of consumer brand knowledge, to see its influence synthetically.

\section{THE CONTENT AND STRUCTURE OF CONSUMER BRAND KNOWLEDGE}

In terms of different types of information in consumer memory, consumer brand knowledge has multiple dimensions, and different dimensions of brand knowledge are likely to have interactive effects [5]. Integrating the multiple dimensions of brand knowledge can improve researcher's ability to understanding consumer response and marketer's ability to marketing better. Therefore, it is an important challenge to develop an integrative model including all kinds of information of brand knowledge. An ideal brand knowledge model should be comprehensive and as parsimonious as possible and can provide the necessary width and depth for understanding consumer behavior and marketing activities.

Associative network model provides a good departure point of understanding consumer brand knowledge and how brand knowledge influence consumer purchase intension. Many researches on brand knowledge are based on this model. One of the most accepted memory structure concept models is associative network memory model. Cognitive psychologists Collins \& Loftus [6] developed associative network model with diffusion-activation concept. A node may be an activator, because it either represents external information (e.g., advertisement, word mouth), or retrieves internal information (a person thinks of a product category). If a specific node in memory is activated, activation will diffuse to the nodes that link to it from this node. Diffusion depends on the number and strength of the links connected to the activated node. Associative network memory model believes that knowledge is an associative network consists of connected nodes in memory, where nodes depict concepts (e.g., brand name and brand association), are stored information sections; links depict relations (e.g., strong or weak; positive or negative) [6-11]. Memory can be seen as an integration of elements with different associative strength [12]. 
On the basis of associative network memory model, brand knowledge can be conceptualized as consisting of a node in memory and many associations connected with it [12] [13]. As the result of activation diffusing, the strength and organization are important determinants of information that can be remembered and will influence brand related decisions of consumer [13] [14]. Brand knowledge has two facets: brand awareness and brand image [13].

\section{A. Brand Awareness}

The first facet of brand knowledge is brand awareness. Brand awareness is the strength of brand node or trace in memory, relates to the likelihood and easiness of brand name appearing in mind, and reflected by consumer ability to recognize brand in different conditions [15]. Brand awareness plays an important role in consumer decision making because: first, it is important whether a consumer can remember a brand when considering buying relevant products. Improving brand awareness increases the probability of brand being included in the consideration set (brands being seriously considered when buying) [16]. Second, brand awareness influences consumer decision making through influencing the formation and strength of brand associations in brand image. A prerequisite of creating brand image is the building of brand node in memory, and the character of brand node influences how different information link with the brand in memory.

\section{B. Brand Image}

The second facet of brand knowledge is brand image. Brand image is people's overall perception on brand and is an important part of consumer information processing as a cognitive concept [17]. Psychology considers perception as a process of people selecting, organizing, and interpreting sensitive stimulation to meaningful and relevant image. Image is an overall perception on object formed by deal with information from different sources over some time. Brand image represents consumer's overall perception on brand, is formed by consumer's deduction on brand, which is founded on external stimulation or imaginer, and is the beliefs on product formatted in consumer experience.

Brand image is reflected by brand associations in consumer memory [18] [13] [14], and is the aggregation of associations relate to brand in consumer memory. Brand association is other information node linked with the brand node in memory, including the implication of brand to consumer. For example, people have such associations on McDonald: Uncle McDonald, golden arch, children, convenience, fast food, quality, service, cleanness, and value, etc. Brand knowledge reflects the retrieval of association and evaluation on brand [19].

\section{THE CREATION AND FORMATION OF CONSUMER BRAND KNOWLEDGE}

The formation process of consumer brand knowledge is an interaction process between firm and consumer. Consumer brand knowledge reflects consumer's perception on brand, and it is influenced by brand identity. Brand identity is brand value proposition, personality, objectives, marks and meaning brought forward by information disseminator, and represents firm's expectation on brand; whereas consumer brand knowledge is the result of consumer's interpretation on brand identity according to all the signals emitted by product, service and brand communication activities, is the deduction on brand meaning, the interpretation on mark, and represents how brand perform actually in consumer's view. Because of the disparity of time, space, social distance, language and culture, mind and idea frame, the twist in brand communication process induces the disparity between brand identity and brand knowledge.

It is important to understand the creation and formation process of consumer brand knowledge for leading consumer perception and increasing brand equity. The knowledge view of memory network is fit for visualizing and monitoring memorable associations but is not fit for explaining knowledge creation process; while the view of organizational knowledge creation theory can explain the creation of brand knowledge. Knowledge creation theory assumes that human knowledge is created in the interaction between tacit knowledge and explicit knowledge. Brand knowledge relates not only with explicit knowledge coming from data interpretation, internal system and process, but also with brand tacit knowledge, which is hidden and usually not shared because it is hard to communicate [20]. Based on knowledge creation theory, we bring forward a creation and formation model of consumer brand knowledge ("Fig. 1").

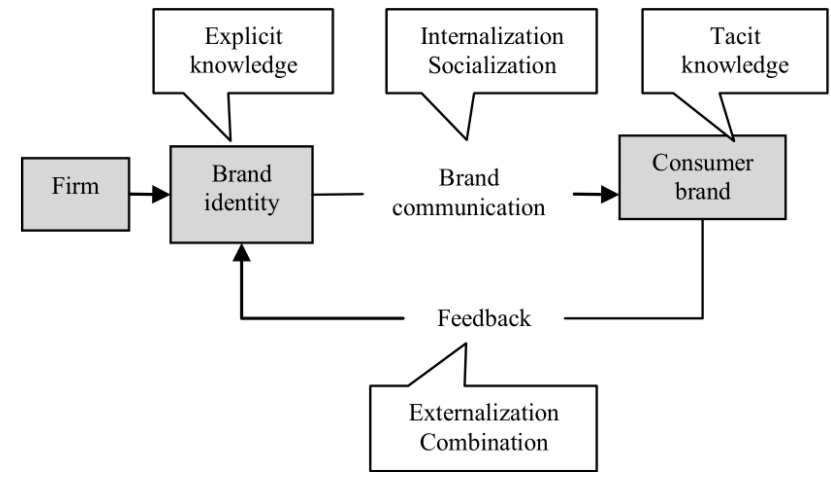

Fig. 1. Creation and formation model of consumer brand knowledge.

Brand identity is a set of identity system proposed by firm that can be expressed clearly with language, words, sound, logo and sign. Brand identity belongs to explicit knowledge. Consumer brand knowledge is personal perception and understanding to brand that exists in consumer's mind, and it belongs to tacit knowledge. Through the four processes: externalization, combination, internalization, and socialization, knowledge continuously transforms between explicit knowledge and tacit knowledge to form a knowledge creation helix. New knowledge is created in the interaction of tacit knowledge and explicit knowledge.

Except for monitoring the existed associations linking with brand node in consumer memory, firm can create necessary nodes in consumer's subjectivity, and dynamically 
lead the nodes in consumer memory to transfer to the direction of firm's expectation. Firm influence consumer brand knowledge by advancing brand identity and communicating it. During this course there are four knowledge transfer models as follows.

\section{A. Externalization: from Tacit Knowledge to Explicit Knowledge}

Externalization transfers personal tacit knowledge into explicit knowledge denoted with words and codes. In the four knowledge transfer models, externalization is very important to knowledge creation because it creates new explicit knowledge from tacit knowledge. Externalization is commonly seen as a concept creation process. Product development personnel and customers express their faith on brand by imagery, analogy and constructing models. They express brand concept in the commercialization of product.

\section{B. Combination: from Explicit Knowledge to Explicit Knowledge}

Combination is the process creating new explicit knowledge by categorizing and combining the explicit knowledge expressed after externalization. Combination embodies the definition and refining of brand identity, combining all kinds of concept into a knowledge system, and constituting brand identity implement system, which includes: the expression of brand positioning, the implement of communication program, and tracking and supervising.

\section{Internalization: from Explicit Knowledge to Tacit Knowledge}

Internalization is the process of recombining the expressed explicit knowledge into personal tacit knowledge. Customer directly acquires product experience by purchasing and using product and forms some faith to brand. Internalization may also happen in occasions without actual experience, for example, customer receiving propaganda about brand or reading brand story can turn brand identity knowledge system into tacit mind mode. Brand information and related association is a part that attaches to memory structure forms over a period of time from different direct and indirect information source [21]. Thereinto associations based on direct experience are more important to person, have bigger associative strength, and greater probability to be retained than those associations based on indirect experience (marketing communication) [22] [23]. Pine \& Gilmore in experience economy [24] and Schmitt in experiential marketing [25] both propose that the importance of "experience value" is increasing, and it is the most important trend in the changing environment around brand. A brand without brand experience will lack of abundant tacit knowledge to provide idea supporting brand meaning.

\section{Socialization: from Tacit Knowledge to Tacit Knowledge}

Socialization is the process of people sharing their experiences and creating tacit knowledge from tacit knowledge. People can learn tacit knowledge by observing, imitating and exercising. Socialization may occur between product developer and customer. The interaction between firm and customer before product developing and after product launching is actually an unending process of sharing tacit knowledge and creating and improving ideas. Product developer can discuss with customer on some possible brand concepts and share customer's opinions on brand. Socialization may occur among customers as well. Those who love a specific brand often will form a brand community to have a feeling of ascription. In this "field" that brand users assemble, they communicate with each other their experience of using brand and their faith on brand, and socialize tacit knowledge through observing, imitating and exercising.

\section{CONCLUSION}

Consumer brand knowledge will influence the validity of future marketing strategy; therefore, it is important to understand the existing and needed consumer brand knowledge structure for effectively increase brand equity. As a kind of tacit knowledge, consumer brand knowledge is the driver of brand operation and the foundation of brand strategy. In brand identity constituting process, firm should emphasize consumer's opinions and feedback, regularly measure and diagnose consumer brand knowledge. In brand identity communication process, firm should use multiple marketing instruments to communicate synthetically, and especially attach importance to experiential marketing. Marketing managers should try to grasp consumer brand cognition, understand how marketing activities affect consumer learning and recalling brand-related information, and thereby provide strategic guidance for brand and marketing decision.

\section{REFERENCES}

[1] T. Levitt, "Marketing myopia," Harvard Business Review, 1960

[2] J.P. Peter, \& J.C. Olson, Consumer Behavior, Irwin, Chicago, 2001.

[3] J.W. Alba, \& A. Chattopadhyay, "The effects of context and partcategory cues on the recall of competing brands," Journal of Marketing Research, 1985, 22, 340-349.

[4] R. Chen, \& F. He, "Examination of brand knowledge, perceived risk and consumers' intention to adopt an online retailer," Total Quality Management \& Business Excellence, 2003, 14(6), 677-693.

[5] K.L. Keller, "Brand synthesis: The multi-dimensionality of brand knowledge," Journal of Consumer Research, 2003, 29(4), 595-600.

[6] A.M. Collins, \& E.F. Loftus, "A spreading-activation theory of semantic processing," Psychological Review, 1975, 82(6), 407-428.

[7] J.G.W. Raaijmakers, \& R.M. Shiffrin, "Search of Associative Memory," Psychological Review, 1981, 88(2), 93-134.

[8] D. Gentner, \& A.L. Stevens, Mental Models. Erlbaum, Hillsdale, NJ, 1983.

[9] R.S. Wyer Jr, \& T.K. Srull, "Human Cognition in Its Social Context," Psychological Review, 1986, 93(3), 322-359.

[10] R. Ratcliff, \& G. McKoon, "A retrieval theory of priming in memory," Psychological Review, 1988, 95(3), 385-408.

[11] P.H. Farquhar, \& P.M. Herr, "The Dual Structure of Brand Associations," Brand Equity and Advertising: Advertising's Role in Building Strong Brands, 1993, 263-277

[12] J.R. Anderson, The Architecture of Cognition, Harvard University Press, Cambridge, MA, 1983. 
[13] K.L. Keller, Strategic brand management, in Building, Measuring and Managing Brand Equity, 2nd ed., Prentice Hall, Pearson Education, Inc., Upper Saddle River, New Jersey, 1998.

[14] K.L. Keller, "Conceptualizing, measuring, and managing customerbased brand equity," Journal of Marketing, 1993, 57, 1-22.

[15] J.R. Rossiter, \& L. Percy, Advertising and Promotion Management, McGraw-Hill Book Company, New York, 1987.

[16] P. Nedungadi, "Recall and consumer consideration sets: influencing choice without altering brand evaluations," Journal of Consumer Research, 1990, 17, 263-276.

[17] K. Blawatt, "Imagery: An alternative approach to the attribute-image paradigm for shopping centres," Journal of Retailing and Consumer Services, 1995, 2(2), 83-96.

[18] H. Herzog, "Behavioral science concepts for analyzing the consumer," In P. Bliss (Ed.), Marketing and the Behavioral Sciences, 76-86, Allyn and Bacon Inc., Boston, 1963.

[19] N. Dawar, "Extensions of broad brands: The role of retrieval in evaluations of fit," Journal of Consumer Psychology, 2001, 5(2), 189207.

[20] R. Ian, F. David, \& M. Ruth, "Brand knowledge management: Growing brand equity," Journal of Knowledge Management, 1998, 2(1), 47.

[21] H.S. Krishnan, "Characteristics of Memory Associations: A Consumer-Based Brand Equity Perspective," International Journal of Research in Marketing, 1996, 13, 385-409.

[22] A.L. Biel, "Converting image into equity," In D. Aaker \& A. Bie (Ed.), Brand Equity and Advertising, Lawrence Erlbaum Associates, Hillsdale, New Jersey, 1993.

[23] A.L. Biel, "How brand image drives brand equity," Journal of Advertising Research, 1993, 6(November/December), 6-12.

[24] B.J. Pine, \& J.H. Gilmore, Experience Economy, Harvard Business School Press, Boston, 1999.

[25] B.H. Schmitt, Experiential Marketing, Free Press, New York, 1999. 